\title{
KOMUNKASI DOSEN PENASEHAT AKADEMIK DALAM PENINGKATAN MUTU DAN KUALITAS MAHASISWA DI STAIN PONTIANAK
}

\author{
Amalia Irfani
}

\begin{abstract}
Abstrak
Tulisan ini bertujuan untuk mengetahui sejauh mana komunikasi-interaksi dosen STAIN Pontianak kepada mahasiswanya sebagai upaya untuk peningkatan mutu dan kualitas pendidikan di STAIN Pontianak. Dalam proses pembelajaran, miss komunikasi menjadi bagian yang tidak mungkin terelakkan sehingga diperlukan upaya untuk meminimalisir perbedaan yang mungkin timbul dengan memaksimalkan komunikasi-interkasi kedua belah pihak (komunikasi dua arah) dilandasi saling pengertian. Komunikasi penting untuk dibangun sebab komunikasi pada hakikatnya adalah kunci semua kehidupan, terlebih pada proses belajar mengajar, komunikasi yang baik, terarah, teratur, terencana akan menghasilkan pembelajaran yang baik pula. Sebaliknya jika komunikasi yang dibangun oleh dosen terhadap mahasiswanya tidak terpola dengan baik, kaku, hasilnya tujuan pembelajaran tidak sesuai dengan yang diharapkan. Banyak kasus dalam instansi pendidikan dosen dalam melakukan interaksi dengan mahasiswa baik secara formal dan non formal lebih banyak menggunakan pendekatan pedagogy (anak-anak) dan bukannya andragogy (orang dewasa). Padahal seperti yang diketahui bahwa mahasiswa adalah orang dewasa yang memiliki karakteristik yang berbeda dengan anak-anak. Selain kurangnya pendekatan andragogy yang dilakukan dosen dalam berinteraksi dengan mahasiswa, faktor lain yang menyebabkan konflik antara dosen dengan mahasiswa adalah terabaikannya pertimbangan moral dan etika oleh masing-masing pihak baik dosen dan mahasiswa.
\end{abstract}

Kata Kunci : komunikasi, dosen penasehat akademik, mutu, kualitas

\section{A. Pendahuluan}

Perguruan tinggi merupakan suatu sistem yang terdiri atas berbagai macam elemen/unsur, utamanya dapat terlihat dari terjadinya komunikasi-interaksi dosen dengan mahasiswa. Komunikasi sebagai bagian dari interaksi merupakan dasar dari proses sosial, dan melalui interaksi yang baik maka akan terbina sebuah hubungan sinergis antara dua kelompok atau lebih. Begitu juga interaksi antara dosen dengan dan mahasiswanya, interaksi atau pola hubungan yang baik jelas melahirkan hasil optimal, sebab 
sesuai dengan fungsinya komunikasi sebenarnya berusaha mengembangkan kreativitas imajinasi, memahami dan mengendalikan diri, serta meningkatkan kematangan berpikir sebelum mengambil keputusan (Cangara, 2000 : 61). khususnya yang berkaitan dengan peningkatan mutu dan kualitas pendidikan, dalam hal ini di STAIN Pontianak. Kualitas kegiatan belajar mengajar atau sering disebut dengan proses pembelajaran tentu saja akan berpengaruh terhadap mutu pendidikan yang output-nya berupa sumber daya manusia.

Implementasi aktivitas belajar mengajar yang sifatnya formal adalah di saat dosen mengajar, membimbing skripsi, perwalian/bimbingan akademik dan sebagainya. Sedangkan pada sisi non formalnya tugas dosen adalah membantu mahasiswa untuk mendapatkan nilai-nilai moral dan nilainilai sosial di luar kegiatan formal tadi, seperti menanamkan kepribadian dan jati diri mahasiswa untuk mengimplementasikan ilmu yang didapat khususnya pada saat menyandang predikat alumni. Dengan demikian keberhasilan kegiatan pembelajaran sangat tergantung kepada efektifitas proses komunikasi yang terjadi dalam proses interaksi kegiatan belajar mengajar.
Dari banyak kasus, biasanya dosen dalam melakukan interaksi dengan mahasiswa baik secara formal dan non formal lebih banyak menggunakan pendekatan pedagogy ( anak-anak) dan bukannya andragogy (orang dewasa). Padahal seperti yang diketahui bahwa mahasiswa adalah orang dewasa yang memiliki karakteristik yang berbeda dengan anak-anak. Selain kurangnya pendekatan andragogy yang dilakukan dosen dalam berinteraksi dengan mahasiswa, faktor lain yang menyebabkan konflik antara dosen dengan mahasiswa adalah terabaikannya pertimbangan moral dan etika oleh masing-masing pihak baik dosen dan mahasiswa. Dosen kadang melaksanakan tugas dan fungsinya sesuai dengan keinginan sendiri atau keinginan institusinya yang diterjemahkan secara kaku, sementara mahasiswa berlaku sesuai dengan ideologi yang dianutnya serta memandang prinsip kesetaraan yang kadang mengabaikan etiket.

Dua faktor tersebut diatas menurut penulis menjadi sumber utama dari disharmonisasi/hambatan interaksi dosen dengan mahasiswa, tanpa terkecuali di STAIN Pontianak. Sikap dosen yang otoriter menyebabkan mahasiswa yang diajarnya bersikap sungkan bahkan malas untuk berkomunikasi, ada pula perilaku 
mengajar dosen yang tidak terpola pada hasil (tidak disiplin misalnya cenderung) pada akhirnya menimbulkan masalah baru dalam proses pembelajaran. Seperti jarang masuk tanpa alasan yang jelas, dan diakhir perkuliahan me-rapel tanda tangan atau pertemuan, atau ada dosen yang tidak memberikan ruang kepada mahasiswanya untuk bereksplorasi mengembangkan kemampuan, sehingga hasil yang ingin didapat tidak sesuai dengan tujuan pembelajaran.

Beberapa mahasiswa yang ada di Jurusan Dakwah misalnya, mengeluhkan sikap dosen yang mereka kategorikan kurang komunikatif, tidak disiplin dalam mengajar atau karena bentrok mengajar karena mendapat jadwal dalam waktu yang bersamaan. Keluhan-keluhan yang muncul karena miss-komunikasi dosenmahasiswa jelas akan berdampak pada tujuan dan hasil pembelajaran.

\section{B. Komunikasi Dosen dan Mahasiswa}

Komunikasi pada hakikatnya merupakan bagian dari interaksi, dan kemampuan berkomunikasi adalah dasar kompetensi paling penting dalam hidup. Soerjono Soekanto (2010) salah seorang pakar sosiologi kenamaan di Indonesia, memberikan definisi tentang interaksi sosial sebagai kunci semua kehidupan sosial, dengan tidak adanya komunikasi ataupun interaksi antar satu sama lain maka tidak mungkin ada kehidupan bersama. la mencontohkan, jika hanya fisik yang saling berhadapan antara satu sama lain, tidak dapat menghasilkan suatu bentuk kelompok sosial yang dapat saling berinteraksi. Maka dari itu dapat disebutkan bahwa interaksi merupakan dasar dari proses sosial karena tanpa adanya interaksi sosial, maka kegiatankegiatan antar satu individu dengan yang lain tidak dapat disebut interaksi.

Dalam pelaksanaan program pendidikan aktivitas menyebarkan, menyampaikan gagasan-gagasan dan maksud-maksud ke seluruh struktur organisasi sangat penting. Sebab proses komunikasi dalam menyampaikan suatu tujuan lebih dari pada sekedar menyalurkan pikiran-pikiran atau gagasan-gagasan dan maksud-maksud secara lisan atau tertulis. Komunikasi secara lisan pada umumnya lebih mendatangkan hasil dan pengertian yang jelas dari pada secara tertulis. Demikian pula komunikasi secara langsung (tatap muka) dan tidak langsung (melalui media internet misalnya) mendatangkan hasil yang berbeda pengaruh dan kejelasannya. Jika komunikator (dalam hal ini dosen) menaruh perhatian kepada saluran-saluran komunikasi tidak langsung, ia akan mengetahui kepentingan dan perhatian komunikan (mahasiswa). Oleh sebab itu suatu proses 
pendidikan akan berhasil apabilla terjadinya suatu proses komunikasi yang baik, terencana, mampu di ukur dan sesuai dengan harapan. Gagasangagasan atau ide dapat dibahas dalam suatu diskusi kelas antara komunikator dan komunikan, sehingga terjadi pemahaman tentang informasi atau segala sesuatu hal menjadi pokok dari pembahasan untuk mengarah pada kesepakatan dan kesatuan dalam pendapat.

Dalam proses keseharian, komunikasi dalam pembelajaran riilnya terbagi atas 2 macam komunikasi, yaitu komunikasi aktif dan komunikasi pasif. Komunikasi aktif merupakan suatu proses komunikasi yang berlangsung dengan aktif antara komunikator dengan komunikan, di mana antara keduanya sama-sama aktif berkomunikasi, sehingga terjadi timbal balik di antara keduanya. Sedangkan komunikasi pasif terjadi di mana komunikator menyampaikan informasi atau ide terhadap komunikannya sebagai penerima informasi saja, akan tetapi komunikan tidak mempunyai kesempatan untuk memberikan respon atau timbal balik dari proses komunikasi.

Terlepas dari bagaimana komunikasi itu di bangun dalam sebuah pembelajaran, kesemuanya dipengaruhi oleh faktor internal dan eksternal. Faktor internal ialah segala faktor yang bersumber dari dalam diri mahasiswa, yakni kemampuan mahasiswa, motivasi, perhatian, persepsi, pemrosesan informasi sedangkan faktor eksternal adalah segala faktor yang bersumber dari luar diri mahasiswa, misalnya kondisi belajar dan pemberian umpan balik yang dilakukan oleh dosen. Jika kedua faktor ini sinergis, maka akan menghasilkan kualitas belajar seperti yang diharapkan.

Cangara $\quad(2000$ :

menguraikan bahwa komunikasi apapun jelas mempunyai tujuan, dan hal tersebut dapat dilihat dari bagaimana khalayak atau komunikan terpengaruh dari apa yang disampaikan komunikator. Pengaruh atau efek menurut Stuart (1988) pembedaan antara apa yang dipikirkan, dirasakan dan dilakukan oleh penerima sebelum dan sesudah menerima pesan. Pengaruh menjadi tolak ukur terpenting untuk mengetahui apakah komunikasi yang dilakukan berhasil atau sebaliknya. Cangara menambahkan, pengaruh dikatakan mengena jika perubahan $(P)$ yang terjadi pada penerima sama dengan tujuan ( $\mathrm{T})$ yang diinginkan oleh komunikator $(P=T)$, yang terlihat dalam bentuk perubahan pengetahuan (knowledge), sikap (attitude), dan perilaku (behavior) serta adanya umpan balik (feedback). Pada tingkat pengetahuan pengaruh bisa terjadi dalam bentuk 
perubahan persepsi dan perubahan pendapat, sikap adanya perubahan internal pada diri seseorang yang diorganisir dalam bentuk prinsip, sebagai hasil evaluasi yang dilakukannya terhadap obyek baik yang terdapat di dalam maupun di luar dirinya. Sedangkan yang dimaksud perubahan perilaku ialah perubahan yang terjadi dalam bentuk tindakan, diakhiri umpan balik berupa data, pendapat, komentar atau saran.

\section{Dosen Penasehat Akademik (PA)}

Dosen penasehat akademik dapat didefinisikan staf pengajar suatu perguruan tinggi yang dianggap cakap

dan mampu memberikan bantuan nasehat akademik kepada para mahasiswa agar dapat menyelesaikan tugasnya sebagai mahasiswa. Bantuan yang diberikan oleh dosen penasehat akademik kepada setiap mahasiswa yang dalam binaannya dimaksudkan agar mahasiswa dapat mengembangkan pandangan, memberikan masukan dalam proses perkuliahan, serta mengambil keputusan dan menanggulangi konsekuensinya sendiri. Peran yang dimainkan dosen Penasehat Akademik di Perguruan Tinggi sebagai berikut :

1. Dengan sistem kredit semester yang diterapkan di perguruan tinggi, setiap mahasiswa memiliki kewajiban untuk merencanakan mata kuliah dan jumlah
SKS yang akan diikutinya berdasarkan Indeks Prestasi semester sebelumnya, sehingga setiap mahasiswa memiliki kesempatan untuk lebih maju berdasarkan kemampuannya masingmasing.

2. Kedudukan dan peran dosen di perguruan tinggi adalah sebagai pengajar, pendidik, pembina, dan pembimbing mahasiswa.

3. Adanya keanekaragaman latar belakang mahasiswa, antara lain lingkungan sosial, budaya, agama, ekonomi, dan pendidikan yang berbeda akan mempengaruhi perkembangan pribadi mahasiswa.

Tugas Umum dan Khusus Dosen PA : 


\begin{tabular}{|c|c|c|}
\hline No & $\begin{array}{c}\text { Tugas Umum } \\
\text { Dosen PA }\end{array}$ & Tugas Khusus Dosen PA \\
\hline 1. & $\begin{array}{lr}\text { Memberikan } & \\
\text { penjelasan } & \\
\text { kepada } & \\
\text { mahasiswa } & \\
\text { tentang } \quad \text { cara } \\
\text { belajar } \quad \text { di } \\
\text { Perquruan Tinqqi }\end{array}$ & $\begin{array}{l}\text { Membuat jadwal pertemuan } \\
\text { berkala antara dosen PA } \\
\text { dengan Mahasiswa yang } \\
\text { dibimbing. }\end{array}$ \\
\hline 2. & $\begin{array}{l}\text { Mengidentifikasi } \\
\text { masalah-masalah } \\
\text { akademik yang } \\
\text { dihadapi } \\
\text { mahasiswa. }\end{array}$ & $\begin{array}{l}\text { Mengadakan } \\
\text { bertemuan } \\
\text { berkala dengan mahasiswa } \\
\text { yang dibimbingnya sesuai } \\
\text { dengan jadwal yang telah } \\
\text { disepakati. }\end{array}$ \\
\hline 3. & $\begin{array}{l}\text { Memberikan } \\
\text { pengarahan } \\
\text { tentang } \\
\text { pentingnya studi } \\
\text { kelompok yang } \\
\text { dikembangkan } \\
\text { dalam diskusi } \\
\text { kelompok belajar. }\end{array}$ & $\begin{array}{l}\text { Menerima keluhan dan } \\
\text { laporan tentang kemajuan } \\
\text { belajar mahasiswa, baik saat } \\
\text { pertemuan terjadwal maupun } \\
\text { di luar acara pertemuan. }\end{array}$ \\
\hline 4. & 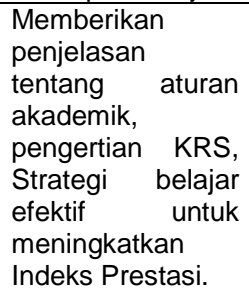 & $\begin{array}{l}\text { Memberi pengarahan kepada } \\
\text { mahasiswa yang dibimbing } \\
\text { tentang berbagai keluhan dan } \\
\text { laporan yang disampaikannya } \\
\text { tentang masalah-masalah } \\
\text { akademik dan atau masalah- } \\
\text { masalah yang dapat } \\
\text { mengganggu proses belajar } \\
\text { mahasiswa. }\end{array}$ \\
\hline 5. & $\begin{array}{l}\text { Menerima laporan } \\
\text { dari mahasiswa } \\
\text { tentang kesulitan- } \\
\text { kesulitan belajar } \\
\text { yang dihadapinya. }\end{array}$ & $\begin{array}{l}\text { Memberikan laporan tertulis } \\
\text { setiap kepada ketua program } \\
\text { studi tentang perkembangan } \\
\text { belajar mahasiswa yang } \\
\text { dibimbingnya. }\end{array}$ \\
\hline 6. & $\begin{array}{l}\text { Mendorong } \\
\text { mahasiswa agar } \\
\text { gemar melakukan } \\
\text { pengkajian bidang } \\
\text { ilmu secara ilmiah } \\
\text { dan melakukan } \\
\text { penelitian. }\end{array}$ & $\begin{array}{l}\text { Menerima salinan Kartu Hasil } \\
\text { Studi (KHS) yang } \\
\text { dibimbingnya pada setiap } \\
\text { akhir semester dan meneliti } \\
\text { kembali keberhasilan studi } \\
\text { mahasiswa. Menandatangani } \\
\text { KRS dan surat permohononan } \\
\text { cuti akademik. }\end{array}$ \\
\hline 7. & - & $\begin{array}{l}\text { Bila dipandang perlu dapat } \\
\text { melakukan konsultasi dengan } \\
\text { pimpinan fakultas tentang } \\
\text { masalah-masalah akademik } \\
\text { yang dihadapi oleh mahasiswa } \\
\text { yang dibimbingnya, termasuk } \\
\text { melakukan komunikasi } \\
\text { dengan orang tua mahasiswa } \\
\text { yang dibimbingnya. }\end{array}$ \\
\hline
\end{tabular}

\section{Komunikasi Efektif Dosen PA dan Mahasiswa}

Mahasiswa sebagai simbol masyarakat akademik pada suatu perguruan tinggi senantiasa menjadi tolok ukur penilaian bagi stakeholder terhadap kualitas almamaternya. Kualitas dirinya menjadi refleksi bagi kualitas almamaternya. Tidak mengherankan mahasiswa senantiasa dituntut kemampuannya untuk menampilkan kompetensi dirinya ke arah pencapaian visi almamaternya. Harapan tersebut tidaklah begitu mudah untuk dicapai, karena mahasiswa sebagai pribadi hanyalah salah satu dari sejumlah komponen yang membangun sistem perguruan tinggi tempat mereka menempa diri. Kesuksesan perputaran roda mekanisme sistem perguruan tinggi sangat ditentukan oleh keharmonisan, keserasian, dan keseimbangan yang berkeadilan dalam pelaksanaan fungsi dan tanggung jawab masing-masing komponen yang membentuk sistem perguruan tinggi tersebut. Demikian pula dalam hal pemerolehan hak-hak masingmasing komponen, termasuk hak-hak mahasiswa dan dosen.

Secara spesifik hak-hak mahasiswa dan dosen dapat berhasil jika komunikasi berlangsung dua arah. Komunikasi adalah sebuah kegiatan mentransfer sebuah informasi baik secara lisan maupun tulisan. Namun, tidak semua orang mampu melakukan komunikasi dengan baik. Terkadang ada orang yang mampu menyampaikan semua informasi secara lisan tetapi tidak mampu secara tulisan ataupun 
sebaliknya. Bagaimanakah caranya agar kita mampu melakukan komunikasi yang baik, komunikasi yang dua arah, komunikasi yang efektif, sehingga target informasi yang harus disampaikan ataupun diserap sesuai dengan harapan, dalam hal ini antara dosen PA dan mahasiswa bimbingannya. Keterampilan dalam berkomunikasi secara efektif dapat dipelajari dan dikuasai dengan latihan rutin dan berkesinambungan secara terus menerus. Untuk dapat melakukan komunikasi efektif antar dosen PA dan mahasiswa bimbingannya, ada beberapa hal yang tidak boleh dilakukan yakni :

1. Menganalisa

2. Menyalahkan

3. Menghakimi

4. Menasehati

5. Menginterogasi

Kelima hal diatas memberikan kontribusi negatif terhadap kelangsungan komunikasi antara dosen PA dan mahasiswanya. Seringkali karena minimnya intensitas pertemuan membuat gap dosen PA dan mahasiswa yang dibimbing. Mahasiswa mengeluh sulit untuk bertemu dosen karena kesibukan dosen yang padat. Untuk sementara dapat dikatakan bahwa akar permasalahan terjadinya kesenjangan komunikasi antara mahasiswa dan PAnya adalah: a. Lemahnya kualitas sosialisasi peraturan akademik dan kemahasiswaan yang diterima oleh mahasiswa pada saat mengikuti masa orientasi pengenalan kampus, demikian pula yang diterima dan dipahami oleh dosen; dan

b. Terputusnya atau tidak adanya tindak lanjut upgreding sosialisasi setelah itu hingga mereka disibukkan denngan aktivitas perkuliahan bagi mahasiswa dan kesibukan mengajar bagi dosen.

Hal penting yang harus diperhatikan adalah keterampilan yang harus dimiliki dalam melakukan komunikasi efektif adalah keterampilan mendengarkan dan bertanya. Dalam proses berkomunikasi, seseorang harus mampu mendengarkan dan memahaminya dengan baik. Kemudian mengajukan pertanyaan-pertanyaan yang saling memiliki keterkaitan dan mengarah pada suatu solusi atau ketenangan untuk masing-masing pihak. Sehingga tujuan utama dalam komunikasi yang efektif adalah sebuah win-win solution. Tak ada satupun orang yang mau disalahkan, inilah konsep dasar dari komunikasi efektif.

Komunikasi efektif atau dalam bahasa lain sering pula disebut diplomasi, perlu dilakukan untuk dapat membangun sebuah kesamaan keinginan sesuai 
tujuan. Sehingga tujuan yang ingin diraih dapat dilakukan secara bersama-sama. Komunikasi efektif dapat dilakukan oleh setiap orang. Jika ada yang merasa tidak mampu, hal ini karena masalah pembiasaan saja. Melatih orang berkomunikasi secara efektif bisa dilakukan dengan langsung pada prakteknya. Walaupun sepintas sepele, hal ini dapat membantu setiap individu/mahasiswa mencapai sebuah kesuksesan baik di dalam kehidupan pribadinya maupun dalam kehidupan karirnya. ${ }^{1}$

\section{E. Penutup}

Dari pemaparan diatas dapat kita ketahui bahwa peran dosen PA menjadi penting dalam rangka menghasilkan lulusan/alumni yang berkualitas. Kurang maksimalnya peran yang dimainkan oleh dosen PA disebabkan padatnya aktifitas mengajar serta belum terjadwalnya bimbingan akademik per semester. Diperlukan keseriusan dari lembaga untuk dapat memaksimalkan peran dosen PA, mulai dari SK penunjukkan, laporan kinerja tiap semester, hingga penyelenggaraan angket kepada mahasiswa untuk mengetahui kinerja dosen, selain reward kepada para dosen yang telah menjalankan tugasnya dengan fungsinya dengan baik.

\section{Daftar Pustaka}

Cangara, Hafied. 2000. Pengantar IImu Komunikasi. Jakarta : PT. Raja Grafindo Persada

http://alisadikinwear.wordpress.com/2012/ 02/08/komunikasi-efektif-dalaminteraksi-dosen-dan-mahasiswa/ http://www.kesling.web.id/id629.htm Maleong, Lexy, J. 1990. Metode Penelitian Kualitatif. Bandung : PT. Remaja Rosdakarya Mulyana, Deddy. 2003. IImu Komunikasi, Bandung : PT. Remaja Rosdakarya Qomar, Mujamil, Prof.Dr. 2007. Manajemen Pendidikan Islam. Malang : Penerbit Erlangga

\footnotetext{
${ }^{1}$ Sumber : http://gofaztrack.com
} 